\title{
Body condition score and its correlation with ultrasonographic back fat thickness in transition crossbred cows
}

\author{
Randhir Singh ${ }^{1}$, S. N. S. Randhawa ${ }^{2}$ and C. S. Randhawa ${ }^{3}$ \\ 1. Department of Veterinary Medicine, Guru Angad Dev Veterinary and Animal Sciences University, Ludhiana, Punjab, \\ India; 2. Department of Veterinary Medicine, Guru Angad Dev Veterinary and Animal Sciences University, Ludhiana, \\ Punjab, India; 3. Department of Veterinary Medicine, Guru Angad Dev Veterinary and Animal Sciences University, \\ Ludhiana Punjab, India. \\ Corresponding author: Randhir Singh, e-mail: dr.randhirlo@gmail.com, SNSR: sarnarinder@gmail.com, \\ CSR: singhcharanjit11@gmail.com
}

Received: 31-10-2014, Revised:18-01-2015, Accepted: 22-01-2015, Published online: 07-03-2015

doi: 10.14202/vetworld.2015.290-294. How to cite this article: Singh R, Randhawa SN, Randhawa CS (2015) Body condition score and its correlation with ultrasonographic back fat thickness in transition crossbred cows, Veterinary World 8(3): $290-294$.

\begin{abstract}
Aim: The aim was to study the effect of the transition to body condition score (BCS) and ultrasonographic back fat thickness (USG BFT) in crossbred cows.

Materials and Methods: A total of 101 multiparous crossbred cows in advanced pregnancy from organized dairy farm were taken up for study. The cows were grouped according to transition stage, i.e. far off dry (FOD), close up dry (CUD) and fresh $(\mathrm{F})$. BCS was estimated by using the five point visual BCS technique with 0.5 increments. The USG BFT was measured by real-time ultrasound using a portable Sonosite instrument.

Results: In cows with BCS 2-2.5, the BFT of F period was significantly lower than FOD period. In cows with BCS 3-3.5, the mean BFT at F period was significantly reduced as compared to FOD and CUD period. The overall correlation coefficient between BCS and BFT for different transition stages was $84 \%, 79 \%$ and $75 \%$ for FOD, CUD and F period, respectively.

Conclusion: The USG BFT gives an accurate measure of fat reserves in cows. The cows with BCS of $\geq 3.5$ entering the transition period are more prone to lose body condition and hence require better and robust management during the transition period.
\end{abstract}

Keywords: body condition score, back fat thickness, cow, transition period.

\section{Introduction}

The body condition scoring (BCS) being a subjective technique is used at regular intervals for assessing the condition of livestock. It is particularly helpful in assessing the body fat reserves of farm animals by visual and manual inspection of the thickness of fat cover and prominence of the bone at the tail head and loin region [1-4]. The BCS system being non-invasive, quick and inexpensive is accepted universally to estimate the degree of fatness [5]. BCS is particularly useful as an aid to dry cow and pre-calving management with the main objective that the cows calve down uneventfully and enter the lactation stage safely [6]. It is also strongly related to milk production and the duration of the postpartum anoestrous interval [7-9]. As the dairy cows use body energy reserves in the early lactation to cope up with negative energy balance [10-15] BCS along with a less common method to assess fat reserves in body tissues i.e. measurement of back fat thickness (BFT) by using real-time ultrasound are more promising approaches to ensure an uneventful transition of dairy cows.

As the cow transition from less demanding non-lactating dry stage to highly stressful lactation

Copyright: The authors. This article is an open access article licensed under the terms of the Creative Commons Attributin License (http:// creative commons.org/licenses/by/2.0) which permits unrestricted use, distribution and reproduction in any medium, provided the work is properly cited. stage there is obvious energy and mineral deficiencies and the major outcomes of these deficiencies are metabolic disorders, reduction in body condition score and reduced reproduction efficiency. Therefore, it is needed of the hour to have an efficient and easily applicable tool to estimate body tissue reserves in dairy cows [16].

The BCS provides an easy and reliable method to evaluate the nutritional status, efficacy of feeding system and to assess changes in energy reserves $[17,18]$. Apart from this, now a days it is widely accepted that the BCS status of a dairy cow indicates nutritional quality, milk yield, reproductive performance, animal well-being and overall farm profitability in a dairy herd [19].

Previously various studies on the precision of BCS system including the ultrasonographic (USG) assessment of subcutaneous back fat indicated that BCS values were closely related to the actual measurement of subcutaneous fat [20]. Few studies were done previously on cross bred cows in India relating to $\mathrm{BCS}$ and BFT, but comprehensive information regarding their relation to transition period is lacking.

Therefore, the objective of this study was to examine the relationship between BCS and BFT using real-time USG in transition cross bred cows.

\section{Materials and Methods}

\section{Ethical approval}

All the procedures have been carried out in accordance with the guidelines laid down by the 
Institutional Ethics Committee and in accordance with local laws and regulations.

\section{Animals}

A total of 101 high yielding multiparous (Milk yield $\geq 25.50$ litre/day) crossbred cows in advanced pregnancy from organized dairy farm were taken up for study conducted during August 2013 to September 2014 in Punjab. The cows were grouped according to transition stage, i.e.,

Far off-dry (FOD): $>10$ days following dry off and not $<30$ days prior to calving

Close up dry (CUD): Between 21 and 3 days prior to calving

Fresh (F): 3-30 days in milk

Same 101 cows were followed up throughout the study to evaluate the changes in body condition score and back fat thickness.

\section{Body composition}

Body condition score (BCS) was estimated by using the five point visual BCS technique with 0.5 increment [21] described in Figure 1.

\section{Back fat thickness (BFT)}

Subcutaneous BFT was measured by real-time ultrasound using a portable Sonosite instrument. BFT was measured in B-mode using $5-10 \mathrm{MHz}$ linear transducer at $7.5 \mathrm{MHz}$ frequency. BFT in the rump or thurl area was measured as the thickness of the layer of sub cutaneous fat between the skin and the fascia trunci profunda located above the gluteus medius muscle. The transducer was placed vertically to an imaginary line between the pins (tuber Ischia) and hooks (tuber coaxe) at the sacral examination site $(9-11 \mathrm{~cm}$ cranial to the pins) [22] after shaving of site and application of coupling gel (Figure-1).

\section{Image measurement and interpretation}

Images were measured at a depth of 4.7. Captured back fat images were freezed and measured using inbuilt measurement calliper protocol in the instrument.

Both BCS and BFT were estimated on the same day at each stage of transition. BCS and USG BFT was measured at all the three periods, i.e. FOD, CUD and $\mathrm{F}$ period in order to observe and calculate any significant change in BCS and BFT.

\section{Feeding and management}

Animals were fed in head to head system in mangers. Feeding involved $45 \mathrm{~kg}$ green fodder (Maize, Pearl millet and Sorghum during summer; Egyptian clover and Oats during winter), $6 \mathrm{~kg}$ of wheat straw and $2 \mathrm{~kg}$ of concentrates per day during last 90 days of gestation. During lactation, the feeding involved $45 \mathrm{~kg}$ green fodder, $8 \mathrm{~kg}$ wheat straw and $3 \mathrm{~kg}$ of concentrates per day.

\section{Statistical analysis}

The USG BFT was presented as mean \pm standard error. The statistical analysis was carried out using
SPSS (16.0). ANOVA followed by Duncan's multiple range test was used to estimate significant difference between BFT at different transition period (FOD, CUD and F) at $p \leq 0.05$. The correlation between BCS and BFT was estimated by Microsoft Excel.

\section{Results}

The mean USG BFT of cows with different body condition scores for different time periods (FOD, CUD, F) is presented in Table-1. In cows with BCS $2-2.5$, the BFT of $F$ period was significantly lower than FOD period but did not differ significantly from FOD to CUD period.

In cows with BCS 3-3.5, the mean BFT at F period was significantly reduced as compared to FOD and CUD period. In cows with BCS group 1-1.5 and $4-4.5$, the mean BFT reduced from FOD to CUD to F period but did not differ significantly. There was no cow having BCS 4.5 and 5.

Out of 38 cows with BCS 2-2.5, 1 cow at CUD and 5 cows at $\mathrm{F}$ periods had a BCS of $<2$ (Table-2). Fifty-four cows had BCS 3-3.5 at FOD period (Table-2). Out of these 54 cows, 11 and 24 cows reduced to BCS 2-2.5 at CUD and F period respectively. All the four cows with BCS 4-4.5 at FOD period reduced to BCS 3-3.5 at CUD and F period.

The overall correlation coefficient between BCS and BFT for different transition stages was $84 \%, 79 \%$ and $75 \%$ for FOD, CUD and F period, respectively.

\section{Discussion}

To the author's knowledge, this is the first study to evaluate the effect of transition period on BCS and BFT concurrently in crossbred cows. Although studies relating BCS and BFT were done previously, but there was the absence of literature regarding evaluation of the changes in BCS or USG BFT at different transition stages. In the present study the BCS was evaluated at three predefined transition stages in crossbred cows on 1-5 scale with 0.5 increments, as a single BCS does not give any indication of whether a cow is gaining or losing body reserves over a period. Furthermore, BFT was concurrently used in this study to validate the BCS, as during the transition it is difficult to judge accurately the real condition of the animal due to weight gain associated with fetal

Table-1: BFT at different transition stages in crossbred cows for different BCS (mean \pm SE)

\begin{tabular}{lccc}
\hline BCS (n) & \multicolumn{3}{c}{ BFT (in cm) } \\
\cline { 2 - 4 } & FOD & CUD & F \\
\hline $1-1.5(05)$ & $0.500 \pm 0.14^{\mathrm{a}}$ & $0.460 \pm 0.15^{\mathrm{a}}$ & $0.418 \pm 0.15^{\mathrm{a}}$ \\
$2-2.5(38)$ & $0.591 \pm 0.02^{\mathrm{a}}$ & $0.549 \pm 0.02^{\mathrm{ab}}$ & $0.493 \pm 0.02^{\mathrm{b}}$ \\
$3-3.5(54)$ & $0.883 \pm 0.01^{\mathrm{a}}$ & $0.842 \pm 0.01^{\mathrm{a}}$ & $0.782 \pm 0.01^{\mathrm{b}}$ \\
$4-4.5(4)$ & $1.12 \pm 0.16^{\mathrm{a}}$ & $1.02 \pm 0.14^{\mathrm{a}}$ & $0.942 \pm 0.13^{\mathrm{a}}$ \\
$5(00)$ & - & - & - \\
\hline *The values with different superscripts in a row differ \\
significantly at p $\leq 0.05$, FOD=Far off dry, CUD=Close \\
up dry, F=Fresh, BFT=Back fat thickness, BCS=Body \\
condition scores, SE=Standard error
\end{tabular}




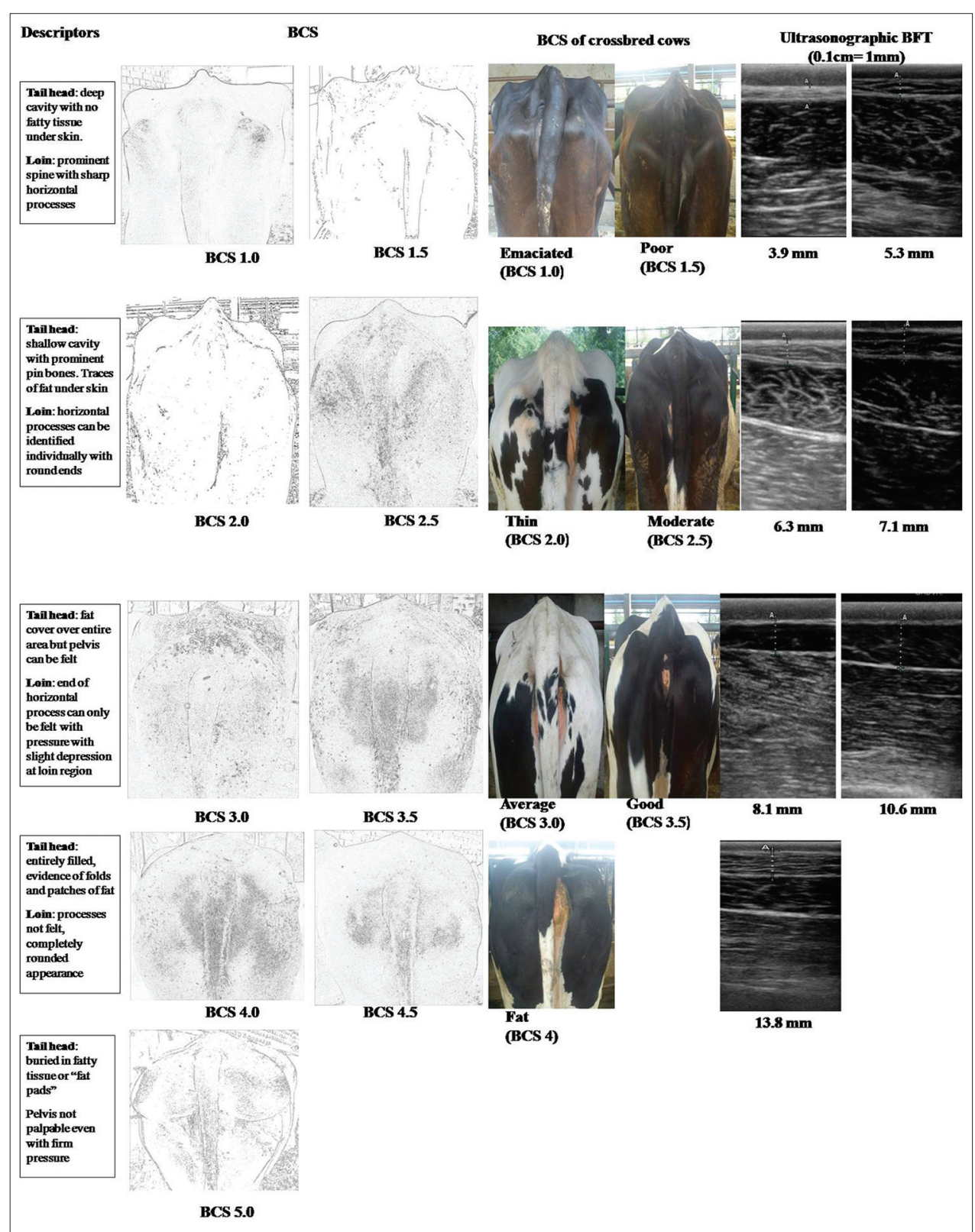

Figure-1: BCS along with principal descriptors and corresponding ultrasonographic BFT in transition crossbred cow

Table-2: Effect of transition period on BCS in crossbred cows

\begin{tabular}{|c|c|c|c|c|c|c|c|c|c|c|c|c|c|c|c|}
\hline \multirow[t]{2}{*}{ BCS } & \multicolumn{5}{|c|}{ FOD } & \multicolumn{5}{|c|}{ CUD } & \multicolumn{5}{|c|}{$\mathbf{F}$} \\
\hline & $<2$ & $2-2.5$ & 3-3.5 & 4-4.5 & 5 & $<2$ & $2-2.5$ & 3-3.5 & 4-4.5 & 5 & $<2$ & $2-2.5$ & 3-3.5 & 4-4.5 & 5 \\
\hline \multirow[t]{4}{*}{ Number of cows } & 5 & - & - & - & - & 5 & - & - & - & - & 5 & - & - & - & - \\
\hline & - & 38 & - & - & - & 1 & 37 & - & - & - & 5 & 33 & - & - & - \\
\hline & - & - & 54 & - & - & - & 11 & 43 & - & - & - & 24 & 30 & - & - \\
\hline & - & - & - & 4 & - & - & - & 4 & - & - & - & - & 4 & - & - \\
\hline
\end{tabular}

*The bold numerical represent the number of cows with reduced BCS from FOD to CUD and or F, FOD=Far off dry, CUD $=$ Close up dry, F=Fresh, BFT=Back fat thickness, BCS=Body condition scores

growth. In our study, the cows with $\mathrm{BCS}>3.5$ were more affected with further change in BCS and BFT in subsequent stages. Similar to our findings Bernabucii et al. [23] reported higher reduction in high BCS cows from late pregnancy to first 30 days in milk, than the cows with average and good BCS. This may be attributed to increased resistance of adipose tissue to insulin that predisposes the dairy animal to mobilize non-esterified fatty acid (NEFA), thus potentially creating a vicious cycle of NEFA mobilization and dry matter intake (DMI) reduction during late prepartum period. This is why high BCS animal have lower DMI and more rapid decrease in BCS during the prepartum period than animal of average or good BCS [24].

USG for BFT was evaluated at the most accepted site, i.e. between pins and hooks. Previously Domecq 
et al. [25] tried to quantify fat reserves in dairy cows by examining lumber, thurl, and tail head areas and found highest correlation $(\mathrm{r}=0.86)$ between right and left sides of the thurl. Our results show there is strong correlation between BCS and BFT for all the three different stages of transition i.e. FOD, CUD and F. This signifies that USG BFT gives an accurate insight about the fat reserves over a period. Similar findings were reported by Anitha et al. [20] with a correlation coefficient of $87 \%$ between BCS and BFT in Murrah buffaloes.

In our study we observed that $67.24 \%(39 / 58)$ cows having BCS above 3 reduced significantly to a lower BCS over the passage of time during transition, where as only $15.78 \%(6 / 38)$ cows having BCS 2-2.5 reduced to a lower BCS. Chebel [26] reported that only $24.7 \%$ of cows entering the dry period with BCS under 3.5 lost BCS during the dry period, whereas $76.6 \%$ of cows over 3.75 lost BCS during the dry period. This difference may be due to the feeding management and environmental differences.

\section{Conclusion}

From this study, it is concluded that cows having BCS 3-3.5 during start of the dry period should be fed balanced energy ration so that they can maintain their condition and cross transition period uneventfully. USG BFT should be concurrently used as an aid to BCS for assessment of body fat reserves in transition cows.

\section{Authors' Contributions}

SNSR designed the experiment. RS carried out the study along with CSR. SNSR and RS analysed the data and prepared the manuscript. CSR reviewed the manuscript. All authors participated in scientific discussion. All authors read and approved the final manuscript.

\section{Acknowledgments}

The study was funded by GADVASU as part of $\mathrm{PhD}$ dissertation of the first author. The authors are highly thankful to the Head, Department of Veterinary Medicine, GADVASU for providing necessary facilities. The authors are also highly thankful to the owner of dairy farm where the study was conducted.

\section{Competing Interests} interests.

The authors declare that they have no competing

\section{References}

1. Vasseur, E., Gibbons, J., Rushen, J. and Passillé, A.M.D. (2013) Development and implementation of a training program to ensure high repeatability of body condition scoring of dairy cows. J. Dairy Sci., 96(7): 4725-4737.

2. Roche, J.R., Berry, D.P. and Kolver, E.S. (2006a) HolsteinFriesian strain and feed effects on milk production, body weight, and body condition score profiles in grazing dairy cows. J. Dairy Sci., 89: 3532-3543.

3. Roche, J.R., Berry, D.P., Lee, J.M., Macdonald, K.A. and
Boston, R.C. (2007a) Describing the body condition score change between successive calvings: A novel strategy generalizable to diverse cohorts. J. Dairy Sci., 90: 4378-4396.

4. Roche, J.R., Blache, D., Kay, J.K., Miller, D.R., Sheahan, A.J. and Miller, D.W. (2008). Neuroendocrine and physiological regulation of intake, with particular reference to domesticated ruminant animals. Nutr. Res. Rev. 21: 207-234.

5. Bittante, G., Gallo, L., Carnier, P., Comin, A. and Cassandro, M. (2004) Management and breeding of cows using body condition score. Inf. Agrario, 60: 55-58.

6. Kirsten, S., Jana, F., Ulrich, M., Susanne, K., Dania, R., Jürgen, R. and Sven, D. (2014) Effects of prepartal body condition score and peripartal energy supply of dairy cows on postpartal lipolysis, energy balance and ketogenesis: An animal model to investigate subclinical ketosis. J. Dairy Res., 81(3): 257-266.

7. Kadivar, A., Ahmadi, M.R. and Vatankhah, M. (2014) Associations of prepartum body condition score with occurrence of clinical endometritis and resumption of postpartum ovarian activity in dairy cattle. Trop. Anim. Health Prod., 46: 121-126.

8. Roche, J.R., Macdonald, K.A., Schütz, K.E., Matthews, L.R., Verkerk, G.A., Meier, S., Loor, J.J., Rogers, A.R., McGowan, J., Morgan, S.R., Taukiri, S. and Webster, J.R. (2013) Calving body condition score affects indicators of health in grazing dairy cows. J. Dairy Sci., 96(9), 5811-5825.

9. Santos, J.E.P., Bisinotto, R.S., Ribeiro, E.S., Lima, F.S., Greco, L.F., Staples, C.R. and Thatcher, W.W. (2010) Applying nutrition and physiology to improve reproduction in dairy cattle. Soc. Reprod. Fertil. Suppl., 67: 387-403.

10. Koenen, E.P.C., Veerkamp, R.F., Dobbelaar, P. and De Jong, G. (2001) Genetic analysis of body condition score of lactating Dutch Holstein and Red-and-White heifers. $J$. Dairy Sci., 84: 1265-1270.

11. Coffey, M.P., Simm, G., Oldham, J.D., Hill, W.G. and Brotherstone S. (2004) Genotype and diet effects on energy balance in the first three lactations of dairy cows. J. Dairy Sci., 87: 4318-4326.

12. Friggens, N.C., Ingvartsen, K.L. and Emmans, G.C. (2004b) Prediction of body lipid change in pregnancy and lactation. J. Dairy Sci., 87: 988-1000.

13. Pryce, J.E. and Harris, B.L. (2006) Genetics of body condition score in New Zealand dairy cows. J. Dairy Sci., 89: 4424-4432.

14. Sumner, J.M. and McNamara, J.P. (2007) Expression of lipolytic genes in the adipose tissue of pregnant and lactating Holstein dairy cattle. J. Dairy Sci., 90: 5237-5246.

15. Berry, D.P., Roche, J.R. and Coffey, M.P. (2008b) Body condition score and fertility - more than just a feeling. In: Royal, M.D., Friggens, N.C. and Smith, R.F., editors. Fertility in Dairy Cows: Bridging the Gaps. British Society of Animal Science, Cambridge University Press, Cambridge, UK. p107-118.

16. Markusfeld, O., Galon, N. and Ezra, E. (1997) Body condition score, health, yield and fertility in dairy cows. Vet. Rec., 141: 67-72.

17. Sheldon, I.M., Lewis, G.S., LeBlanc, S. and Gilbert, R.O. (2006) Defining postpartum uterine disease in cattle. Theriogenology, 65, 1516-1530.

18. Edmonson, A.J., Lean, I.J., Weaver, L.D., Farver, T. and Webster, G., (1989) A body condition scoring chart for Holstein Dairy cows. J. Dairy Sci., 72: 68-78.

19. Bewley, J.M. and Schutz, M.M. (2008) Review: An interdisciplinary review of body condition scoring for dairy cattle. Prof. Anim. Sci., 24: 507-529.

20. Anitha, A., Sarjan R.K., Suresh J., Srinivasa, M.P.R. and Kotilinga, R.Y. (2010) Development of the body condition score system in Murrah buffaloes: Validation through ultrasonic assessment of body fat reserves. J. Vet. Sci., 11(1): 1-8. 21. Wildman, E.E., Jones G.M., Wagner, P.E., Boman, R.L., 
Troutt, J.R. and Lesch, T.N. (1982) A dairy cow body condition scoring system and its relationship to selectedproduction characteristics. J. Dairy Sci. 65: 495-501.

22. Nanda, P.J. and Herdt, T.H. (2009) Clinical use of ultrasound for subcutaneous fat thickness measurements in dairy cattle. Curr. Vet. Ther. Food Anim. Pract., 5: 150-153.

23. Bernabucci, U., Ronchi, B., Lacetera, N. and Nardone, A. (2005) Influence of body condition score on relationships between metabolic status and oxidative stress in periparturient dairy cows. J. Dairy Sci., 88: 2017-2026.

24. Lucy, M.C., Verkerk, G.A., Whyte, B.E., Macdonald, K.A., Burton, L., Cursons, R.T., Roche, J.R. and Holmes, C.W.
(2009) Somatotropic axis components and nutrient partitioning in genetically diverse dairy cows managed under different feed allowances in a pasture system. J. Dairy Sci., 92: 526-539.

25. Domecq, J.J., Skidmore, A.L., Lloyd, J.W. and Kaneene, J.B. (1995) Validation of body condition scores with ultrasound measurements of subcutaneous fat of dairy cows. J. Dairy Sci., 78: 2308-2313.

26. Chebel, C.R. (2010) The long lasting impact of reproductive performance on health and production. West. Dairy News., 10(10): http://www.cvmbs.colostate.edu/ilm/proinfo/wdnnewsletter.htm Last accesed on 04-01-2015.

$* * * * * * * *$ 